\title{
Molecular structure, hydrogen bonding and spectroscopic properties of the complex of piperidine-4-carboxylic acid with chloroacetic acid
}

\author{
A. Komasa, A. Katrusiak, M. Szafran *, P. Barczyński, Z. Dega-Szafran \\ Faculty of Chemistry, Adam Mickiewicz University, Grunwaldzka 6, 60-780 Poznań, Poland
}

Received 27 November 2007; accepted 24 January 2008

Available online 2 February 2008

\begin{abstract}
Complex of piperidine-4-carboxylic acid with chloroacetic acid has been studied by X-ray diffraction, FTIR, Raman, ${ }^{1} \mathrm{H}$ and ${ }^{13} \mathrm{C}$ NMR spectroscopy and $\mathrm{B} 3 \mathrm{LYP} / 6-31 \mathrm{G}(\mathrm{d}, \mathrm{p})$ calculations. In crystal the piperidine ring is protonated and adopts a chair conformation with the $\mathrm{COOH}$ group in the equatorial position. The $\mathrm{COO}^{-}$group of chloroacetate unit is engaged in three hydrogen bonds: $\mathrm{O}(1)-\mathrm{H}(1) \cdots \mathrm{O}(3)$ of $2.604(2) \AA, \mathrm{N}(1)-\mathrm{H}(12) \cdots \mathrm{O}(3)$ of $2.753(2) \AA$ and $\mathrm{N}(1)-\mathrm{H}(11) \cdots \mathrm{O}(4)$ of $2.760(2) \AA$. According to the B3LYP calculations the isolated complexes both in vacuum and $\mathrm{H}_{2} \mathrm{O}$ solution have cyclic structures. In vacuum the molecules are connected by two H-bonds: the $\mathrm{COOH}$ group of chloroacetic acid is engaged with piperidine-4-carboxylic acid, one with the nitrogen atom, $\mathrm{O}(4)-$ $\mathrm{H} \cdots \mathrm{N}(1)$ of $2.658 \AA$ and the second with carboxyl group, $\mathrm{O}(1)-\mathrm{H} \cdots \mathrm{O}(3)$ of $2.860 \AA$. In water solution piperidine-4-carboxylic acid is protonated and forms two hydrogen bonds with the chloroacetate unit: $\mathrm{N}(1)-\mathrm{H} \cdots \mathrm{O}(4)$ of $2.690 \AA$ and $\mathrm{O}(1)-\mathrm{H} \cdots \mathrm{O}(3)$ of $2.611 \AA$. Powder FTIR spectra of the complex and its deuterated analogue are consistent with the X-ray structure. Correlations between the experimental ${ }^{1} \mathrm{H}$ and ${ }^{13} \mathrm{C}$ chemical shifts of the complex investigated and the GIAO/B3LYP/6-31G(d,p) calculated magnetic isotropic shielding tensors $\left(\sigma_{\text {calc }}\right)$ in vacuum and within the conductor-like screening continuum solvation model $(\mathrm{COSMO})$ in $\mathrm{H}_{2} \mathrm{O}$, $\delta_{\text {exp }}=a+b \sigma_{\text {calc }}$, are reported.
\end{abstract}

(c) 2008 Elsevier B.V. All rights reserved.

Keywords: Piperidine-4-carboxylic acid; Chloroacetic acid; Hydrogen bonds; X-ray diffraction; FTIR, Raman and NMR spectra; DFT calculations

\section{Introduction}

Piperidine-4-carboxylic acid (isonipecotic acid) crystallizes as a monohydrate of zwitterionic form [1,2]. The piperidine ring adopts a chair conformation and the carboxyl group is in the equatorial position. Recently we have studied piperidine-4-carboxylic acid hydrochloride [3]. In this paper the structure, conformation and hydrogen bonds of piperidine-4-carboxylic acid complex with chloroacetic acid are analyzed by X-ray diffraction, FTIR, Raman, ${ }^{1} \mathrm{H}$ and ${ }^{13} \mathrm{C}$ NMR spectroscopy and $\mathrm{B} 3 \mathrm{LYP} / 6-31 \mathrm{G}(\mathrm{d}, \mathrm{p})$ calculations.

\footnotetext{
* Corresponding author. Tel.: +48 061829 1320; fax: +48 0618291505. E-mail address: szafran@amu.edu.pl (M. Szafran).
}

\section{Experimental}

\subsection{Synthesis}

Complex of piperidine-4-carboxylic acid with chloroacetic acid was obtained by mixing of piperidine-4-carboxylic acid monohydrate $(0.02 \mathrm{~mol}$ in methanol:water $4: 1)$ with chloroacetic acid $(0.02 \mathrm{~mol}$ in methanol). The mixture was stirred at room temperature for $2 \mathrm{~h}$. After 2 days the colorless crystals were filtered off and recrystallized from methanol, yield $65 \%$, mp. $225-228^{\circ} \mathrm{C}$. Analysis: exp. and (calc.) \% 42.72 (42.96); \%H 6.47 (6.31), \%N 6.13 (6.26). A deuterated sample was obtained by twice exchange with $\mathrm{D}_{2} \mathrm{O}$ followed by removal of excess $\mathrm{D}_{2} \mathrm{O}$ and recrystallization from $\mathrm{CH}_{3} \mathrm{OD}$. 


\subsection{Instrumentation}

The X-ray diffraction measurements of complex of piperidine-4-carboxylic acid with chloroacetic acid were carried out using a KUMA KM-4 diffractometer. The structure was solved by direct methods with the SHELXS-97 program [4] and refined by the full-matrix least squares method on $F^{2}$ data using the SHELXL-97 [5] program. The crystal data and details concerning the data collection and structure refinement are given in Table 1, while the atomic coordinates are in Table 2. The parameters in the CIF form are available as Electronic Supplementary Information from Cambridge Crystallografic Data-base Centre (CCDC 668647).

FTIR spectra were measured on a Bruker IFS 66v/S spectrometer, evacuated to avoid water and $\mathrm{CO}_{2}$ absorption. Solid state spectra were recorded in Nujol and Fluorolube suspensions. Each spectrum consisted of 64 scans. The Raman spectrum was measured on a Bruker FRA 106/S instrument.

${ }^{1} \mathrm{H}$ and ${ }^{13} \mathrm{C}$ NMR spectra were recorded on a Varian Gemini 300 VT spectrometer operating at 300.07 and $75.46 \mathrm{MHz}$ for proton and carbon-13, respectively, in $\mathrm{D}_{2} \mathrm{O}$ solutions, in $5 \mathrm{~mm}$ tubes. The chemical shifts were measured to the internal standard of 3-(trimethylsilyl)propionic- $d_{4}$ acid sodium salt. The assignments of the chemical shifts were confirmed by COSY and HETCOR experiments.

\subsection{B3LYP calculations}

The calculations were performed using the Gaussian 03 program package [6] and B3LYP [7-9] method in conjunc-

Table 1

Crystal data and structure refinement for the complex of 4-piperidinecarboxylic acid with chloroacetic acid

\begin{tabular}{ll}
\hline Empirical formula & $\mathrm{C}_{8} \mathrm{H}_{14} \mathrm{ClNO}_{4}$ \\
Formula weight & 223.65 \\
Temperature (K) & $293(2)$ \\
Wavelength $(\AA)$ & 0.71073 \\
Crystal system & Orthorhombic \\
Space group & $P$ nna $2_{1}$ \\
Unit cell dimensions $(\AA)$ & \\
$a=12.1486(5)$ & \\
$b=9.6405(3)$ & \\
$c=8.9490(5)$ & $1048.09(8)$ \\
Volume $\left(\AA^{3}\right)$ & 4 \\
$Z$ & 1.417 \\
Calculated density $\left(\mathrm{g} / \mathrm{cm}^{3}\right)$ & 0.354 \\
Absorption coefficient $\left(\mathrm{mm}^{-1}\right)$ & 472 \\
$F(000)$ & $0.50 \times 0.35 \times 0.30$ \\
Crystal size (mm) & $2.70-32.05$ \\
$\theta$ range for data collection $\left({ }^{\circ}\right)$ & $-14 / 18,-14 / 14,-13 / 11$ \\
Limiting indices $h, k, l$ & Full-matrix least-squares on $F^{2}$ \\
Refinement method & $8399 / 3211 / 0.0159$ \\
Reflections collected/unique/ $R($ int $)$ & $95.3 \%$ \\
Completeness to $\theta=32.05^{\circ}$ & $3211 / 1 / 151$ \\
Data/restraints/parameters & 1.083 \\
Goodness-of-fit on $F^{2}$ & $R_{1}=0.0341, w R_{2}=0.0817$ \\
Final $R$ indices $[I>2 \sigma(I)]$ & $R_{1}=0.0525, w R_{2}=0.0949$ \\
$R$ indices (all data) & 0.301 and -0.419 \\
Largest diff. peak and hole $\left(\mathrm{e} \AA^{-3}\right)$ &
\end{tabular}

Table 2

Atomic coordinates and equivalent isotropic displacement parameters for the complex of 4-piperidinecarboxylic acid with chloroacetic acid

\begin{tabular}{|c|c|c|c|c|}
\hline Atom & $x$ & $y$ & $z$ & $U(\mathrm{eq})$ \\
\hline $\mathrm{Cl}(1)$ & $0.9629(1)$ & $0.5302(1)$ & $0.4144(1)$ & $0.072(1)$ \\
\hline $\mathrm{O}(3)$ & $0.9373(1)$ & $0.1612(1)$ & $0.2409(2)$ & $0.040(1)$ \\
\hline $\mathrm{O}(4)$ & $0.8133(1)$ & $0.3256(1)$ & $0.2781(2)$ & $0.050(1)$ \\
\hline $\mathrm{C}(8)$ & $1.0031(2)$ & $0.3706(2)$ & $0.3332(3)$ & $0.041(1)$ \\
\hline $\mathrm{C}(9)$ & $0.9076(1)$ & $0.2825(2)$ & $0.2803(2)$ & $0.029(1)$ \\
\hline $\mathrm{N}(1)$ & $0.6284(1)$ & $-0.5089(1)$ & $0.2610(2)$ & $0.033(1)$ \\
\hline $\mathrm{C}(2)$ & $0.6000(1)$ & $-0.3818(2)$ & $0.3496(2)$ & $0.034(1)$ \\
\hline$C(3)$ & $0.6907(1)$ & $-0.2743(2)$ & $0.3370(2)$ & $0.032(1)$ \\
\hline $\mathrm{C}(4)$ & $0.7122(1)$ & $-0.2394(2)$ & $0.1720(2)$ & $0.028(1)$ \\
\hline $\mathrm{C}(5)$ & $0.7414(1)$ & $-0.3707(2)$ & $0.0862(2)$ & $0.030(1)$ \\
\hline$C(6)$ & $0.6505(1)$ & $-0.4775(2)$ & $0.0999(2)$ & $0.033(1)$ \\
\hline $\mathrm{C}(7)$ & $0.8001(1)$ & $-0.1294(2)$ & $0.1567(2)$ & $0.031(1)$ \\
\hline $\mathrm{O}(1)$ & $0.7749(1)$ & $-0.0147(1)$ & $0.2277(2)$ & $0.054(1)$ \\
\hline $\mathrm{O}(2)$ & $0.8838(1)$ & $-0.1449(1)$ & $0.0866(2)$ & $0.049(1)$ \\
\hline $\mathrm{H}(21)$ & 0.5898 & -0.4068 & 0.4537 & 0.040 \\
\hline $\mathrm{H}(22)$ & 0.5315 & -0.3429 & 0.3131 & 0.040 \\
\hline $\mathrm{H}(31)$ & 0.7576 & -0.3098 & 0.3822 & 0.039 \\
\hline $\mathrm{H}(32)$ & 0.6694 & -0.1908 & 0.3902 & 0.039 \\
\hline $\mathrm{H}(4)$ & $0.6461(12)$ & $-0.1986(15)$ & $0.1354(18)$ & $0.013(3)$ \\
\hline $\mathrm{H}(51)$ & 0.7527 & -0.3482 & -0.0183 & 0.036 \\
\hline $\mathrm{H}(52)$ & 0.8094 & -0.4090 & 0.1252 & 0.036 \\
\hline $\mathrm{H}(61)$ & 0.5840 & -0.4425 & 0.0533 & 0.039 \\
\hline $\mathrm{H}(62)$ & 0.6719 & -0.5619 & 0.0485 & 0.039 \\
\hline $\mathrm{H}(11)$ & $0.6852(19)$ & $-0.5510(20)$ & $0.2960(20)$ & $0.048(6)$ \\
\hline $\mathrm{H}(12)$ & $0.5719(18)$ & $-0.5760(20)$ & $0.2710(20)$ & $0.050(6)$ \\
\hline $\mathrm{H}(1)$ & $0.8280(20)$ & $0.0380(30)$ & $0.2150(30)$ & $0.070(8)$ \\
\hline $\mathrm{H}(81)$ & $1.0391(19)$ & $0.3230(30)$ & $0.4050(40)$ & $0.067(8)$ \\
\hline $\mathrm{H}(82)$ & $1.0520(20)$ & $0.3850(30)$ & $0.2580(30)$ & $0.063(7)$ \\
\hline
\end{tabular}

$U($ eq $)$ is defined as one third of the trace of the orthogonalized $U_{i j}$ tensor.

tion with $6-31 \mathrm{G}(\mathrm{d}, \mathrm{p})[10]$ basis set. The magnetic isotropic shielding tensors were calculated with the standard GIAO/ B3LYP/6-31G(d,p) (Gauge-Independent Atomic Orbital) approach using the conductor-like screening continuum solvation model (COSMO) [11-17] and geometries listed in Table 2.

\section{Results and discussion}

\subsection{Molecular parameters}

The molecular structure and atomic numbering of piperidine-4-carboxylic acid-chloroacetic acid complex are shown in Fig. 1 and the projection of the crystal structure along plane (001) is presented in Fig. 2. The bond lengths, bond and torsion angles are listed in Table 3 . The piperidine ring is protonated and adopts a chair conformation. The carboxylic substituent at the $\mathrm{C}(4)$ atom assumes the equatorial position and forms the $\mathrm{O}(1)-\mathrm{H}(1) \cdots \mathrm{O}(3)$ hydrogen bond with the chloroacetate anion of the length 2.604(2) A. Both protons of the $\mathrm{N}^{+} \mathrm{H}_{2}$ group are engaged in $\mathrm{N}-\mathrm{H} \cdots \mathrm{O}$ hydrogen bonds with two neighboring chloroacetate anions of the lengths 2.753(2) and 2.760(2) $\AA$, respectively (Table 4). In the crystal the $\mathrm{O}-\mathrm{H} \cdots \mathrm{O}$ and $\mathrm{N}-$ $\mathrm{H}$... O hydrogen bonds (Table 4) bind the molecules into $\mathrm{H}$-bonded sheets parallel to the crystallographic planes (001), shown in Fig. 2. 


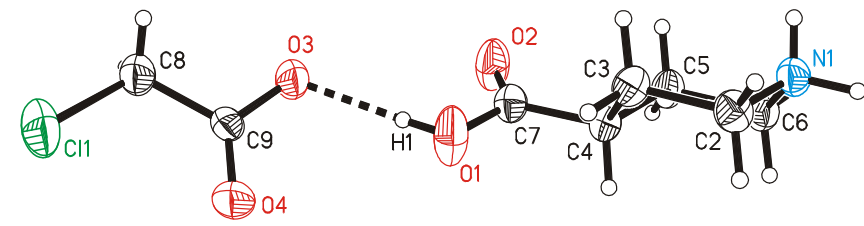

Fig. 1. Atom numbering for the complex of piperidine-4-carboxylic acid with chloroacetic acid. The H-bond is shown as the dashed line. The thermal ellipsoids have been drawn at the $50 \%$ probability level.

The molecular arrangement in the crystal is clearly dominated by strong hydrogen bonds and contacts involving chlorine atoms. The shortest chlorine-chlorine distance is of 4.602(1) $\AA$ (symmetry code: $2-x, 1-y, 0.5+z$ ). Intermolecular $\mathrm{Cl} \cdots \mathrm{O}$ distances are also longer than $4 \AA$. However there are intermolecular $\mathrm{Cl} \cdots \mathrm{H}$ contacts commensurate with the sum of van der Waals radii of $\mathrm{Cl}$ and $\mathrm{H}$ atoms: $\mathrm{Cl}(1) \cdots \mathrm{H}(31)$ of $2.95 \AA$, symmetry code $x, 1+y, z$ and $\mathrm{Cl}(1) \cdots \mathrm{H}(32)$ of $2.96 \AA$, symmetry code $0.5+x$, $0.5-y, z$. These data confirm the role of $\mathrm{Cl} \cdots \mathrm{H}$ contacts in the molecular association in crystal. Analogous contacts have been observed in simple halogenated alcohols [18-22].

Structures of the complex predicted by calculations at the B3LYP/6-31G $(d, p)$ level of theory are quite different in comparison with that in the crystal (Fig. 3). The isolated complexes in vacuum have a cyclic structure, connected by two hydrogen bonds, one between the $\mathrm{COOH}$ group of chloroacetic acid with nitrogen atom of piperidine-4-carboxylic acid, $\mathrm{O}(4)-\mathrm{H} \cdots \mathrm{N}(1)$ of length $2.658 \AA$ and the second bond between the $\mathrm{COOH}$ groups of both acids, $\mathrm{O}(1)-\mathrm{H} \cdots \mathrm{O}(3)$ of $2.860 \AA$ (Table 4). According to the COSMO approach, in water solution the proton from chloroacetic acid is transferred to the nitrogen atom of piperidine-4-carboxylic acid and the cyclic complex is stabilized by two H-bonds, $\mathrm{N}(1)-\mathrm{H} \cdots \mathrm{O}(4)$ and $\mathrm{O}(1)-\mathrm{H} \cdots \mathrm{O}(3)$ of lengths 2.690 and $2.611 \AA$, respectively.

\subsection{The experimental FTIR and Raman spectra}

The FTIR solid state spectra of the investigated complex and its deuterated analogue are shown in Fig. 4. The $\mathrm{O}(1)$ $\mathrm{H}(1) \cdots \mathrm{O}(3), \quad \mathrm{N}(1)-\mathrm{H}(12) \cdots \mathrm{O}(3)$ and $\mathrm{N}(1)-\mathrm{H}(11) \cdots \mathrm{O}(4)$ hydrogen bonds identified in the crystal structure are manifested in the FTIR spectrum by the overlapping $v \mathrm{NH}_{2}$ and $v \mathrm{OH}$ vibrations that give rise to a broad band in the 3200 $2100 \mathrm{~cm}^{-1}$ region. There are seven local maxima at 3080 , $3002,2974,2829,2736,2661$ and $2528 \mathrm{~cm}^{-1}$ on this broad absorption and its center of gravity $\left(v^{\prime}=\int v \log \left(I_{\mathrm{o}} / I\right) \mathrm{d} v /\right.$ $\int \log \left(I_{\mathrm{o}} / I\right) \mathrm{d} v$, where $I_{\mathrm{O}}$ is the intensity of radiation incident on the sample at wave numbers at $v$ and $I$ is the transmittance intensity, calculated with $\mathrm{d} v=0.96 \mathrm{~cm}^{-1}$ ) is at $2678 \mathrm{~cm}^{-1}$. The $v \mathrm{ND}_{2}$ and $v \mathrm{OD}$ stretching vibrations are identified in the range $2400-2000 \mathrm{~cm}^{-1}$ and its center of gravity is at $2276 \mathrm{~cm}^{-1}$. The isotope ratio of the center of

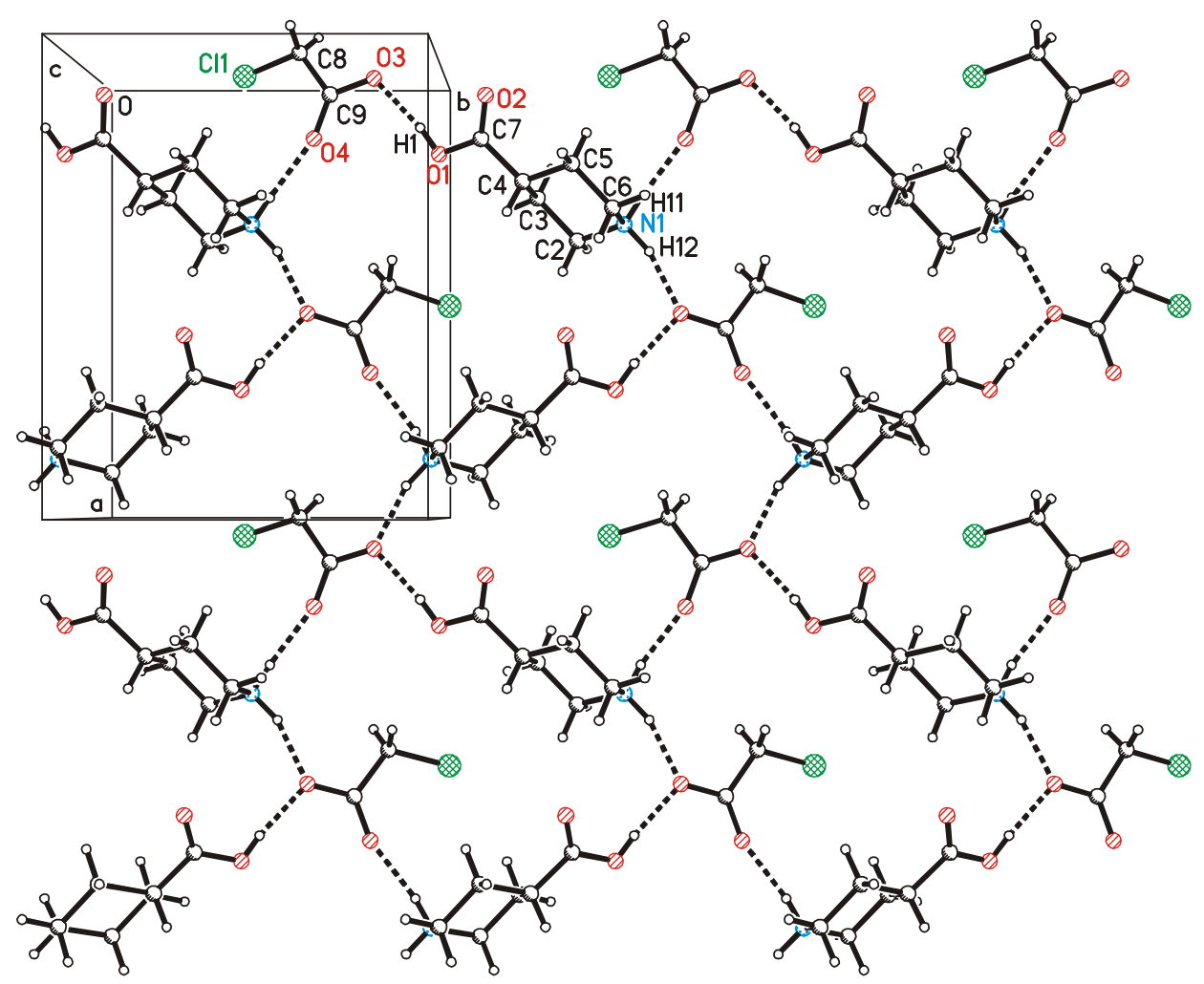

Fig. 2. Autostereographic projection [26] of the molecular arrangement in the complex of piperidine-4-carboxylic acid with chloroacetic acid crystal viewed along the $(001)$ plane. The hydrogen bonds are shown as the dashed lines. 
Table 3

Bond lengths $(\AA)$, angles and torsion angles $\left(^{\circ}\right)$ for the complex of piperidine-4-carboxylic acid with chloroacetic acid determined by X-ray diffraction and B3LYP/6-31G $(\mathrm{d}, \mathrm{p})$ calculations in vacuum and $\mathrm{H}_{2} \mathrm{O}$ solution

\begin{tabular}{|c|c|c|c|}
\hline & X-ray & B3LYP & \\
\hline & & In vacuum & In water $^{\mathrm{a}}$ \\
\hline Bond lengths & & & \\
\hline $\mathrm{Cl}(1)-\mathrm{C}(8)$ & $1.770(2)$ & 1.797 & 1.821 \\
\hline $\mathrm{O}(3)-\mathrm{C}(9)$ & $1.274(2)$ & 1.228 & 1.262 \\
\hline $\mathrm{O}(4)-\mathrm{C}(9)$ & $1.218(2)$ & 1.305 & 1.255 \\
\hline $\mathrm{C}(8)-\mathrm{C}(9)$ & $1.514(2)$ & 1.525 & 1.540 \\
\hline $\mathrm{N}(1)-\mathrm{C}(6)$ & $1.497(2)$ & 1.481 & 1.501 \\
\hline $\mathrm{N}(1)-\mathrm{C}(2)$ & $1.500(2)$ & 1.481 & 1.501 \\
\hline$C(2)-C(3)$ & $1.517(2)$ & 1.529 & 1.525 \\
\hline$C(3)-C(4)$ & $1.537(3)$ & 1.547 & 1.548 \\
\hline $\mathrm{C}(4)-\mathrm{C}(7)$ & $1.512(2)$ & 1.532 & 1.527 \\
\hline$C(4)-C(5)$ & $1.522(2)$ & 1.547 & 1.548 \\
\hline$C(5)-C(6)$ & $1.515(2)$ & 1.529 & 1.525 \\
\hline $\mathrm{C}(7)-\mathrm{O}(2)$ & $1.204(2)$ & 1.209 & 1.220 \\
\hline $\mathrm{C}(7)-\mathrm{O}(1)$ & $1.311(2)$ & 1.349 & 1.336 \\
\hline Bond angles & & & \\
\hline $\mathrm{C}(9)-\mathrm{C}(8)-\mathrm{Cl}(1)$ & $113.81(13)$ & 116.5 & 115.4 \\
\hline $\mathrm{O}(4)-\mathrm{C}(9)-\mathrm{O}(3)$ & $125.11(14)$ & 126.6 & 125.1 \\
\hline $\mathrm{O}(4)-\mathrm{C}(9)-\mathrm{C}(8)$ & $122.31(14)$ & 116.3 & 119.6 \\
\hline $\mathrm{O}(3)-\mathrm{C}(9)-\mathrm{C}(8)$ & $112.58(13)$ & 117.1 & 111.4 \\
\hline $\mathrm{C}(6)-\mathrm{N}(1)-\mathrm{C}(2)$ & $112.68(13)$ & 111.2 & 112.1 \\
\hline $\mathrm{N}(1)-\mathrm{C}(2)-\mathrm{C}(3)$ & $110.59(13)$ & 109.7 & 109.5 \\
\hline $\mathrm{C}(2)-\mathrm{C}(3)-\mathrm{C}(4)$ & $110.13(14)$ & 111.7 & 111.9 \\
\hline$C(7)-C(4)-C(5)$ & $111.94(13)$ & 111.3 & 110.7 \\
\hline $\mathrm{C}(7)-\mathrm{C}(4)-\mathrm{C}(3)$ & $111.09(13)$ & 111.3 & 110.7 \\
\hline $\mathrm{C}(5)-\mathrm{C}(4)-\mathrm{C}(3)$ & $110.02(12)$ & 111.8 & 111.7 \\
\hline$C(6)-C(5)-C(4)$ & $110.76(13)$ & 111.7 & 111.9 \\
\hline $\mathrm{N}(1)-\mathrm{C}(6)-\mathrm{C}(5)$ & $110.24(14)$ & 109.7 & 109.5 \\
\hline $\mathrm{O}(2)-\mathrm{C}(7)-\mathrm{O}(1)$ & $123.65(15)$ & 120.6 & 120.0 \\
\hline $\mathrm{O}(2)-\mathrm{C}(7)-\mathrm{C}(4)$ & $123.82(15)$ & 122.7 & 122.7 \\
\hline $\mathrm{O}(1)-\mathrm{C}(7)-\mathrm{C}(4)$ & $112.53(14)$ & 116.6 & 117.3 \\
\hline Torsion angles & & & \\
\hline $\mathrm{Cl}(1)-\mathrm{C}(8)-\mathrm{C}(9)-\mathrm{O}(4)$ & $8.3(3)$ & -1.4 & 0.03 \\
\hline $\mathrm{Cl}(1)-\mathrm{C}(8)-\mathrm{C}(9)-\mathrm{O}(3)$ & $-171.22(14)$ & 178.8 & 180.0 \\
\hline $\mathrm{C}(6)-\mathrm{N}(1)-\mathrm{C}(2)-\mathrm{C}(3)$ & $-56.59(19)$ & -63.4 & -61.3 \\
\hline $\mathrm{N}(1)-\mathrm{C}(2)-\mathrm{C}(3)-\mathrm{C}(4)$ & $56.12(18)$ & 55.3 & 54.9 \\
\hline $\mathrm{C}(2)-\mathrm{C}(3)-\mathrm{C}(4)-\mathrm{C}(7)$ & $178.38(12)$ & -173.8 & -174.1 \\
\hline $\mathrm{C}(2)-\mathrm{C}(3)-\mathrm{C}(4)-\mathrm{C}(5)$ & $-57.11(17)$ & -48.6 & -50.2 \\
\hline$C(7)-C(4)-C(5)-C(6)$ & $-178.42(14)$ & 173.8 & 174.1 \\
\hline$C(3)-C(4)-C(5)-C(6)$ & $57.56(18)$ & 48.6 & 50.2 \\
\hline $\mathrm{C}(2)-\mathrm{N}(1)-\mathrm{C}(6)-\mathrm{C}(5)$ & $56.47(18)$ & 63.4 & 61.3 \\
\hline $\mathrm{C}(4)-\mathrm{C}(5)-\mathrm{C}(6)-\mathrm{N}(1)$ & $-56.70(18)$ & -55.3 & -54.9 \\
\hline $\mathrm{C}(5)-\mathrm{C}(4)-\mathrm{C}(7)-\mathrm{O}(2)$ & $-0.9(2)$ & 117.3 & 117.7 \\
\hline $\mathrm{C}(3)-\mathrm{C}(4)-\mathrm{C}(7)-\mathrm{O}(2)$ & $122.5(2)$ & -117.3 & -117.8 \\
\hline $\mathrm{C}(5)-\mathrm{C}(4)-\mathrm{C}(7)-\mathrm{O}(1)$ & $178.72(15)$ & -62.7 & -62.2 \\
\hline $\mathrm{C}(3)-\mathrm{C}(4)-\mathrm{C}(7)-\mathrm{O}(1)$ & $-57.86(19)$ & 62.8 & 62.3 \\
\hline
\end{tabular}

${ }^{a}$ Data calculated using the conductor-like screening solvation model $($ COSMO $) ; \operatorname{scrf}=(\mathrm{cpcm}$, solvent $=$ water $)$.

gravity, $v \mathrm{H} / v \mathrm{D}$, is equal to 1.2 . In the Raman spectra, the intensity of the $v \mathrm{OH}$ frequency is very weak [23] and in the complex investigated this absorption band is absent, while the intensity of the $v \mathrm{NH}_{2}$ absorption is medium. The strong absorption in FTIR spectrum at 1628 and $1616 \mathrm{~cm}^{-1}$ is attributed to the $v_{\mathrm{as}} \mathrm{COO}$ vibration in chloroacetate anion and confirms that proton is transferred from the chloroacetic acid to piperidine-4-carboxylic acid. The band at
$1689 \mathrm{~cm}^{-1}$ is due to the $v \mathrm{C}=\mathrm{O}$ vibration of the $\mathrm{COOH}$ group in piperidine-4-carboxylic acid. In the Raman spectrum these bands are at 1632 and $1688 \mathrm{~cm}^{-1}$, respectively.

\subsection{NMR spectra}

The experimental ${ }^{1} \mathrm{H}$ and ${ }^{13} \mathrm{C}$ NMR chemical shifts in $\mathrm{D}_{2} \mathrm{O}$ of the investigated complex are listed in Tables 5 and 6 . The proton chemical shift assignments were based on the 2D COSY [24] in which the proton-proton connectivity are observed through the off-diagonal peaks in the counter plot. The 2D heteronuclear shifts correlated contour maps (HETCOR) [23] were used to identity resonance in the ${ }^{13} \mathrm{C}$ NMR spectra.

Correlation plots of the experimental chemical shifts $\left(\delta_{\text {exp }}\right)$ in $\mathrm{D}_{2} \mathrm{O}$ versus the calculated GIAO magnetic isotropic shielding tensors $\left(\sigma_{\text {calc }}\right)$ are shown in Fig. 5. Following the approach of Forsyth and Sebag [25] to the empirical scaling of theoretical data, the linear regressions, $\delta_{\exp }=a$ $+b \sigma_{\text {calc }}$, were made; details are summarized in Tables 5 and 6 for hydrogens and carbons, respectively. As shown by the correlation coefficients $\left(r^{2}\right)$ listed in Tables 5 and 6 , the agreement between the experimental and calculated chemical shifts in vacuum is good for carbon-13 $\left(r^{2}=0.994-0.999\right)$ and poor for proton $\left(r^{2}=0.667-0.768\right)$. The $r^{2}$ values predicted by the conductor-like screening continuum solvation model are slightly lower (Tables 5 and 6). The protons are located on the periphery of the molecule and thus are supposed to be more efficient in intermolecular (solute-solvent) effects than the carbons. For this reason the agreement between the experimental and calculated data for proton is not as good as for carbon-13.

\section{Conclusions}

In crystal the piperidine ring of the complex of piperidine-4-carboxylic acid with chloroacetic acid is protonated and adopts a chair conformation with the $\mathrm{COOH}$ group in the equatorial position, which forms the $\mathrm{O}(1)-\mathrm{H}(1) \cdots \mathrm{O}(3)$ hydrogen bond with chloroacetate anion of the length 2.604(2) $\AA$. Both protons of the $\mathrm{N}^{+} \mathrm{H}_{2}$ group are engaged in $\mathrm{N}-\mathrm{H} \cdots \mathrm{O}$ hydrogen bonds with two neighboring chloroacetate anions of lengths 2.753(2) and 2.760(2) $\AA$, respectively (Table 4). In the crystal, the molecules form sheets connected by the $\mathrm{N}-\mathrm{H} \cdots \mathrm{O}$ and $\mathrm{O}-\mathrm{H} \cdots \mathrm{O}$ hydrogen bonds.

The isolated complex optimized in vacuum by the B3LYP/6-31G $(\mathrm{d}, \mathrm{p})$ method has a cyclic structure, connected by two hydrogen bonds, one between the $\mathrm{COOH}$ group of chloroacetic acid with the nitrogen atom of piperidine-4-carboxylic acid $(\mathrm{O}-\mathrm{H} \cdots \mathrm{N}$ of the length $2.658 \AA$ ) and the other bond between the $\mathrm{COOH}$ groups of both acids $(\mathrm{O}-\mathrm{H} \cdots \mathrm{O}$ of the length $2.860 \AA)$. According to the COSMO model, in water solution piperidine-4-carboxylic acid is protonated and forms two hydrogen bonds with the chloroacetate unit: $\mathrm{N}(1)-\mathrm{H} \cdots \mathrm{O}(4)$ of $2.690 \AA$ and $\mathrm{O}(1)-\mathrm{H} \cdots \mathrm{O}(3)$ of $2.611 \AA$. 
Table 4

Geometry of hydrogen bonds in the complex of piperidine-4-carboxylic acid with chloroacetic acid, energy (a.u.) and dipole moments (Debye)

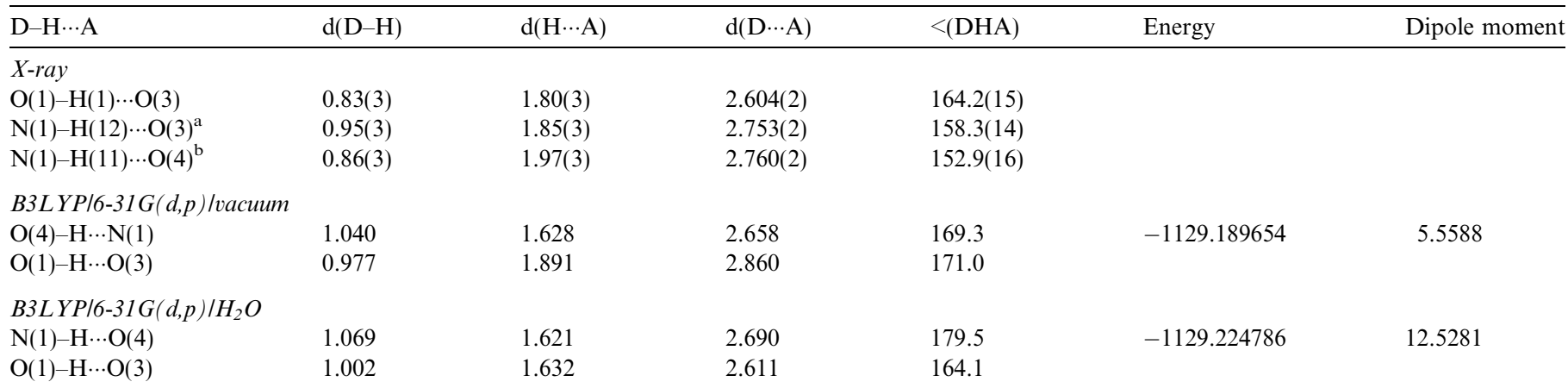

Symmetry codes: (a) $x-0.5,-y-0.5, z$; (b) $x, y-1.0, z$.

a
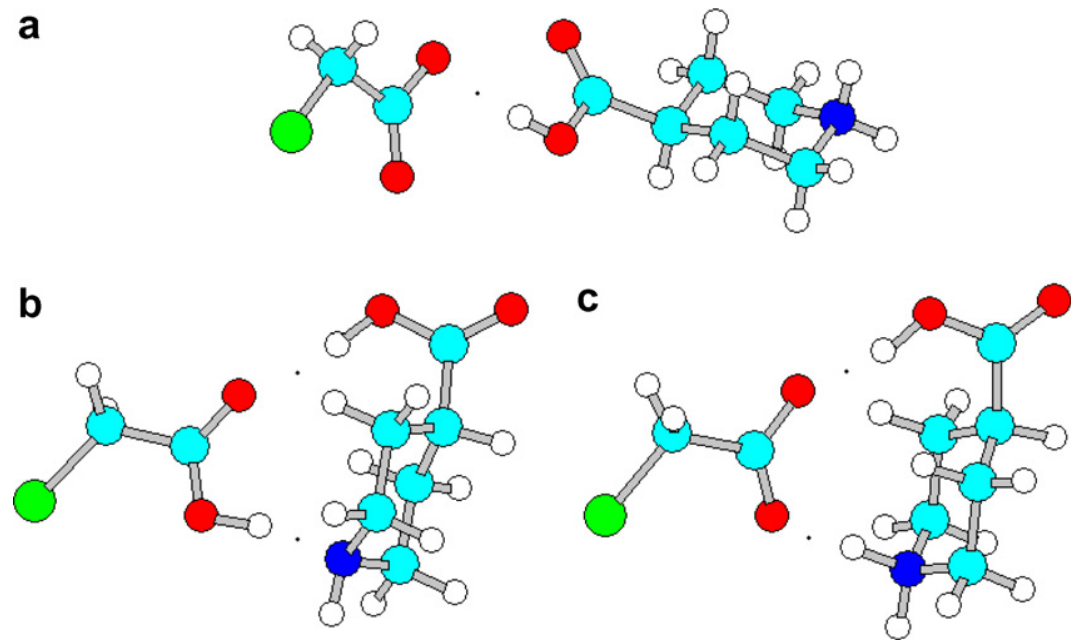

Fig. 3. Comparison of the structure of the complex of piperidine-4-carboxylic acid with chloroacetic acid determined by X-ray diffraction (a) and calculated by the B3LYP/6-31G(d,p) approach for isolated molecule in vacuum (b) and in water (c).

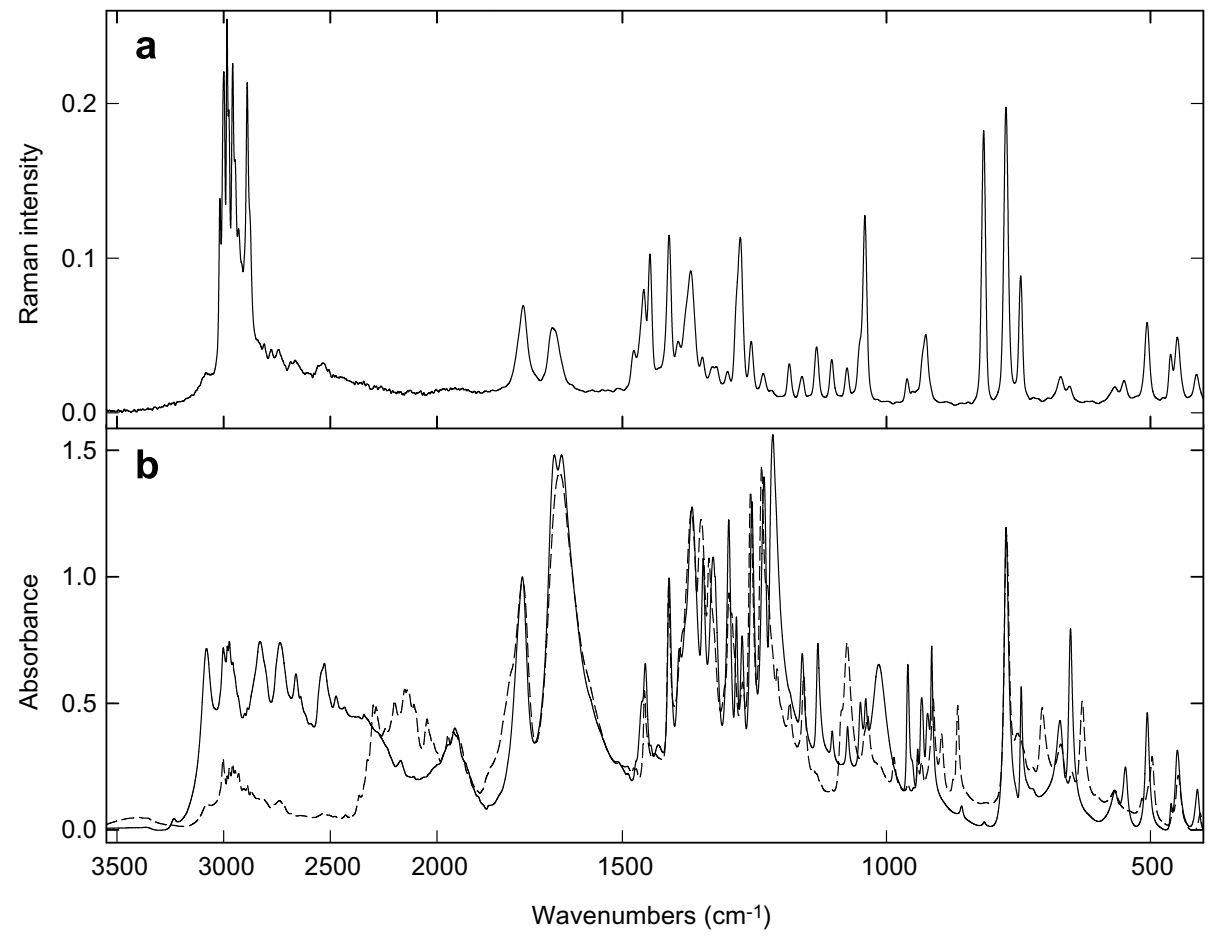

Fig. 4. Experimental spectra of the complex of piperidine-4-carboxylic acid with chloroacetic acid: (a) the Raman spectrum in the solid state and (b) the FTIR spectrum in Nujol and Fluorolube emulsions, dashed line denote the spectrum of a deuterated sample. 
Table 5

Experimental $\left(\delta_{\text {exp }}\right)$ and predicted $\left(\delta_{\text {pred }}\right){ }^{1} \mathrm{H}$ chemical shifts $(\mathrm{ppm})$ and calculated GIAO/B3LYP/6-31G $(\mathrm{d}, \mathrm{p})$ magnetic isotropic ${ }^{1} \mathrm{H}$ shielding tensors $\left(\sigma_{\text {calc }}\right)$ in vacuum and $\mathrm{H}_{2} \mathrm{O}$ for complexes of piperidine-4-carboxylic acid with chloroacetic acid; $\left(\delta_{\text {pred }}=a+b \sigma_{\text {calc }}\right)$

\begin{tabular}{|c|c|c|c|c|c|}
\hline \multirow[t]{2}{*}{ Atom } & \multirow{2}{*}{$\frac{\delta_{\text {exp }}}{\mathrm{D}_{2} \mathrm{O}}$} & \multicolumn{2}{|l|}{$\delta_{\text {pred }}$} & \multicolumn{2}{|l|}{$\sigma_{\text {calc }}$} \\
\hline & & Vacuum & $\mathrm{H}_{2} \mathrm{O}$ & Vacuum & $\mathrm{H}_{2} \mathrm{O}$ \\
\hline H-2ax & & & & 29.1010 & 28.6753 \\
\hline H-6ax & & & & 29.1019 & 28.6750 \\
\hline H-2,6ax & 3.06 & 2.8691 & 2.8132 & 29.1013 & 28.6752 \\
\hline H-2eq & & & & 28.6847 & 28.2906 \\
\hline H-6eq & & & & 28.6844 & 28.2883 \\
\hline H-2,6eq & 3.43 & 3.2590 & 3.1530 & 28.6846 & 28.2895 \\
\hline H-3ax & & & & 29.3597 & 28.9927 \\
\hline H-5ax & & & & 29.3568 & 28.9986 \\
\hline H-3,5ax & 1.83 & 2.6286 & 2.5308 & 29.3583 & 28.9957 \\
\hline H-3eq & & & & 30.1787 & 29.8787 \\
\hline H-5eq & & & & 30.1805 & 29.8749 \\
\hline H-3,5eq & 2.14 & 1.8602 & 1.7544 & 30.1796 & 29.8768 \\
\hline $\mathrm{H}-4$ & 2.63 & 2.5253 & 3.1495 & 29.4687 & 28.2935 \\
\hline $\mathrm{C}-\mathrm{H}$ & & & & 27.8909 & 27.6126 \\
\hline C-H & & & & 27.8783 & 27.6131 \\
\hline $\mathrm{CH}_{2}$ & 4.06 & 4.0077 & 3.7492 & 27.8844 & 27.6129 \\
\hline$a$ & & & & 30.097677 & 28.079489 \\
\hline$b$ & & & & -0.935648 & -0.881121 \\
\hline$r^{2}$ & & & & 0.76856 & 0.66719 \\
\hline
\end{tabular}

Table 6

Experimental $\left(\delta_{\text {exp }}\right)$ and predicted $\left(\delta_{\text {pred }}\right){ }^{13} \mathrm{C}$ chemical shifts $(\mathrm{ppm})$ and calculated GIAO/B3LYP/6-31G $\left(\mathrm{d}\right.$,p) magnetic isotropic ${ }^{13} \mathrm{C}$ shielding tensors $\left(\sigma_{\text {calc }}\right)$ in vacuum and $\mathrm{H}_{2} \mathrm{O}$ for complexes of piperidine-4-carboxylic acid with chloroacetic acid; $\left(\delta_{\text {pred }}=a+b \sigma_{\text {calc }}\right)$

\begin{tabular}{|c|c|c|c|c|c|}
\hline \multirow[t]{2}{*}{ Atom } & \multirow{2}{*}{$\frac{\delta_{\text {exp }}}{\mathrm{D}_{2} \mathrm{O}}$} & \multicolumn{2}{|l|}{$\delta_{\text {pred }}$} & \multicolumn{2}{|l|}{$\sigma_{\text {calc }}$} \\
\hline & & Vacuum & $\mathrm{H}_{2} \mathrm{O}$ & Vacuum & $\mathrm{H}_{2} \mathrm{O}$ \\
\hline $\mathrm{C}-2$ & & & & 145.2372 & 146.6618 \\
\hline C-6 & & & & 145.2298 & 146.6552 \\
\hline C- 2,6 & 46.50 & 46.7484 & 45.2902 & 145.2335 & 146.6585 \\
\hline $\mathrm{C}-3$ & & & & 164.8164 & 166.9853 \\
\hline C-5 & & & & 164.8210 & 166.9865 \\
\hline$C-3,5$ & 27.83 & 24.6276 & 22.9507 & 164.8187 & 166.9875 \\
\hline C-4 & 42.35 & 45.6748 & 43.8515 & 146.1840 & 147.9677 \\
\hline $\mathrm{CH}_{2}$ & 46.50 & 46.6128 & 52.5386 & 145.3535 & 140.0624 \\
\hline $\mathrm{C}(7)$ & 177.34 & 178.2126 & 182.6707 & 28.8385 & 21.6418 \\
\hline$C(9)$ & 182.27 & 180.9137 & 175.4885 & 26.4470 & 28.1776 \\
\hline$a$ & & & & 210.784683 & 206.452779 \\
\hline$b$ & & & & -1.129466 & -1.098897 \\
\hline$r^{2}$ & & & & 0.99908 & 0.99468 \\
\hline
\end{tabular}
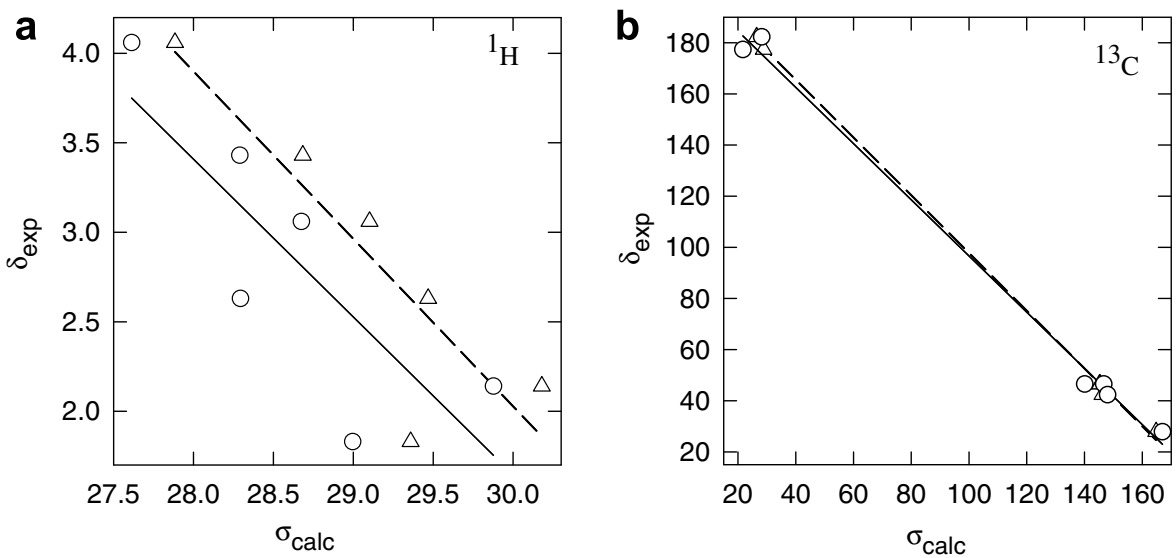

Fig. 5. Plot of the experimental chemical shifts (ppm, $\delta_{\exp }$ ) of the complex of piperidine-4-carboxylic acid with chloroacetic acid versus the magnetic isotropic shielding tensors (ppm, $\sigma_{\text {calc }}$ ) from GIAO/B3LYP/6-31G(d,p) (a) proton, (b) carbon-13; $\Delta$ - data in vacuum, $\bigcirc$ - data in water. 
The FTIR spectrum shows a broad band in the 3090 $2100 \mathrm{~cm}^{-1}$ region due to the overlapping $v \mathrm{NH}_{2}$ and $v \mathrm{OH}$ vibrations and two bands at 1689 and $1628-1615 \mathrm{~cm}^{-1}$ corresponding to the $v \mathrm{C}=\mathrm{O}$ and $v_{\mathrm{as}} \mathrm{COO}$ vibrations, respectively. In the Raman spectrum absorption due to the $\nu \mathrm{OH}$ vibration is absent. The powder FTIR spectrum of the complex is consistent with the X-ray structure.

The magnetic isotropic shielding tensors were calculated by the standard GIAO/B3LYP/6-31G(d,p) (Gauge-Independent Atomic Orbital) approach in vacuum and in terms of the conductor-like screening solvation model (COSMO) getting good linear correlations with the experimental ${ }^{13} \mathrm{C}$ chemical shifts.

\section{Acknowledgements}

The calculations were performed at the Poznan Supercomputing and Networking Centre.

\section{References}

[1] G. Delgado, A.J. Mora, A. Bahsas, Acta Crystallogr. C57 (2001) 965.

[2] A.J. Mora, G. Delgado, B.M. Ramirez, L. Rincon, R. Almeida, J. Cuervo, A. Bahsas, J. Mol. Struct. 615 (2002) 201.

[3] M. Szafran, A. Komasa, E. Bartoszak-Adamska, J. Mol. Struct. 827 (2007) 101.

[4] G.M. Sheldrick, SHELXS-97, Program for Solution Crystal Structure, University of Göttingen, Göttingen, 1997.

[5] G.M. Sheldrick, SHELXL-97, Program for Crystal Structure Refinement, University of Göttingen, Göttingen, 1997.

[6] M.J. Frisch, G.W. Trucks, H.B. Schlegel, G.E. Scuseria, M.A. Robb, J.R. Cheeseman, J.A. Montgomery Jr., T. Vreven, K.N. Kudin, J.C. Burant, J.M. Millam, S.S. Iyengar, J. Tomasi, V. Barone, B. Mennucci, M. Cossi, G. Scalmani, N. Rega, G.A. Petersson, H. Nakatsuji, M. Hada, M. Ehara, K. Toyota, R. Fukuda, J. Hasegawa, M. Ishida, T. Nakajima, Y. Honda, O. Kitao, H. Nakai, M. Klene, X. Li, J.E. Knox, H.P. Hratchian, J.B. Cross, C. Adamo, J. Jaramillo, R.
Gomperts, R.E. Stratmann, O. Yazyev, A.J. Austin, R. Cammi, C. Pomelli, J.W. Ochterski, P.Y. Ayala, K. Morokuma, G.A. Voth, P. Salvador, J.J. Dannenberg, V.G. Zakrzewski, S. Dapprich, A.D. Daniels, M.C. Strain, O. Farkas, D.K. Malick, A.D. Rabuck, K. Raghavachari, J.B. Foresman, J.V. Ortiz, Q. Cui, A.G. Baboul, S. Clifford, J. Cioslowski, B.B. Stefanov, G. Liu, A. Liashenko, P. Piskorz, I. Komaromi, R.L. Martin, D.J. Fox, T. Keith, M.A. AlLaham, C.Y. Peng, A. Nanayakkara, M. Challacombe, P.M.W. Gill, B. Johnson, W. Chen, M.W. Wong, C. Gonzalez, J.A. Pople, GAUSSIAN 03, Revision B.05, Gaussian, Inc., Pittsburgh, PA, 2003.

[7] A.D. Becke, J. Chem. Phys. 98 (1994) 5648.

[8] P.J. Stephens, F.J. Devlin, C.F. Chabalowski, M.J. Frisch, J. Phys. Chem. 98 (1994) 11623.

[9] T.J. Dunning Jr., J. Chem. Phys. 90 (1989) 1007.

[10] W.J. Hehre, L. Random, P.v.R. Schleyer, J.A. Pople, Ab Initio Molecular Orbital Theory, Wiley, New York, 1989.

[11] K. Wolinski, J.F. Hinton, P. Pulay, J. Am. Chem. Soc. 112 (1990) 8251.

[12] P. Pulay, X. Zhou, F. Fogarasi, in: R. Fausto (Ed.), Recent Experimental and Computational Advances in Molecular Spectroscopy, Kluwer, Academic, Netherlands, 1993, pp. 88-111.

[13] A. Klamt, COSMO and COSMO-RS, in: Encyclopedia of Computational Chemistry, P.V.R. Schleyer (Ed.), Wiley, New York, 1998.

[14] V. Barone, M. Cossi, J. Phys. Chem. A 102 (1998) 1995.

[15] M. Cossi, G. Scalmani, N. Rega, V. Barone, J. Chem. Phys. 117 (2002) 43.

[16] F. Eckert, A. Klamt, AIChE J. 48 (2002) 369.

[17] B. Ośmiałowski, E. Kolehmainen, R. Gawinecki, Magnet. Reson. Chem. 39 (2001) 334, and references cited therein.

[18] M. Podsiadło, A. Katrusiak, Acta Cryst. B63 (2007) 903.

[19] R. Gajda, A. Katrusiak, Acta Cryst. B63 (2007) 896.

[20] M. Bujak, K. Dziubek, A. Katrusiak, Acta Cryst. B63 (2007) 124.

[21] M. Podsiadło, A. Katrusiak, Acta Cryst. B63 (2007) 1071.

[22] M. Bujak, M. Podsiadło, A. Katrusiak, J. Phys. Chem. B 112 (2008) 1184.

[23] B. Schrader (Ed.), Infrared and Raman Spectroscopy. Methods and Applications, VCH, Weinheim, 1995.

[24] S. Braun, H.-O. Kalinowski, S. Berger, 100 and More Basic NMR Experiments. A Practical Course, Springer, Weinheim, 1996.

[25] D.A. Forsyth, A.B. Sebag, J. Am. Chem. Soc. 119 (1997) 9483.

[26] A. Katrusiak, J. Mol. Graph Model. 19 (2001) 363. 